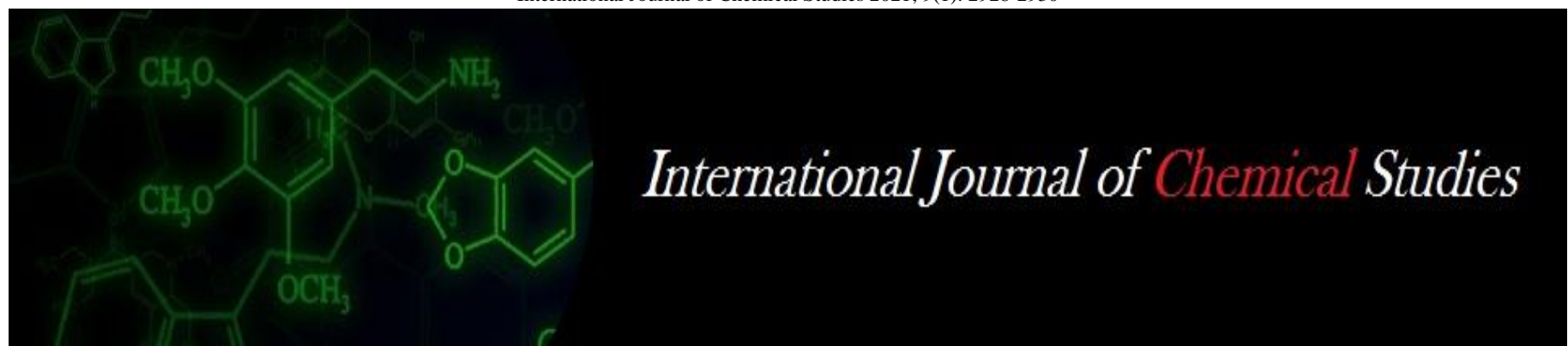

P-ISSN: 2349-8528

E-ISSN: 2321-4902

www.chemijournal.com

IJCS 2021; 9(1): 2928-2930

(C) 2021 IJCS

Received: 13-10-2020

Accepted: 30-12-2020

Manojgowda BS

M.Sc. Scholar, Department of

Agronomy, SHUATS, Prayagraj,

Uttar Pradesh, India

Rajesh Singh

Assistant Professor, Department

of Agronomy, SHUATS,

Prayagraj, Uttar Pradesh, India

Wasim Khan

Ph.D., Research Scholar,

Department of Agronomy,

SHUATS, Prayagraj,

Uttar Pradesh, India
Corresponding Author:

Manojgowda BS

M.Sc. Scholar, Department of

Agronomy, SHUATS, Prayagraj,

Uttar Pradesh, India

\section{Influence of different spacing and nutrient sources on yield and economic of Zaid finger millet (Eleusine coracana (L.) Gaertn) under eastern UP condition}

\author{
Manojgowda BS, Rajesh Singh and Wasim Khan
}

DOI: https://doi.org/10.22271/chemi.2021.v9.i1ao.11674

\begin{abstract}
A field experiment was conducted during Zaid season 2020 at Crop Research Farm (CRF), Department of Agronomy, SHUATS, Prayagraj (UP) on sandy loam soil to investigate the influence of different spacing and nutrient sources on yield and economic of Zaid finger millet (Eleusine coracana (L.) Gaertn) under eastern UP condition. The treatments consisted of spacing viz., $20 \mathrm{~cm} \mathrm{x} 10 \mathrm{~cm}, 30 \mathrm{~cm} \times 10 \mathrm{~cm}$ and $40 \mathrm{~cm} \times 10 \mathrm{~cm}$ and nutrient sources viz., 100\% RDN, 100\% N through vermicompost and 50\% RDN + $50 \% \mathrm{~N}$ through vermicompost whose effect is observed on finger millet (var. Godra-OT). The experiment was laid out in randomized block design with nine treatments replicated thrice. Study revealed that spacing of $20 \mathrm{~cm} \times 10 \mathrm{~cm}+50 \% \mathrm{RDN}+50 \% \mathrm{~N}$ through vermicompost was recorded significantly higher grain yield $(2.74 \mathrm{t} / \mathrm{ha})$ and biological yield $(7.41 \mathrm{t} / \mathrm{ha})$ as compared to all the treatment combinations. The economic analysis clearly indicates that higher $\mathrm{B}: \mathrm{C}$ ratio (1.90) recorded with treatment of spacing $20 \mathrm{~cm} \times 10 \mathrm{~cm}+50 \% \mathrm{RDN}+50 \% \mathrm{~N}$ through vermicompost as compared to all treatment combinations.
\end{abstract}

Keywords: finger millet, spacing, recommended dose of nitrogen, vermicompost, yield, economics

\section{Introduction}

In India, finger millet is cultivated in an area of 1.27 million ha with a production of 2.61 million tonnes and an average productivity of $1489 \mathrm{~kg} / \mathrm{ha}$. (FAI, 2018) ragi (finger millet) alone occupies $20.5 \%$ out of total area occupied by small millets. Finger millet is good for prevention of premature aging. It has been growing for time immemorial as a dual-purpose crop where crop production and animal husbandry go hand in hand. In finger millet, health benefits epidemiological studies indicated that regular consumption of whole grain and its products can protect against the risk of cardio-vascular diseases, type II diabetes, obesity, gastro-intestinal cancers and range of other disorders (Mckeown, 2002) ${ }^{[5]}$. The grain content $9.2 \%$ proteins, $1.29 \%$ fats, $76.32 \%$ carbohydrates, $2.2 \%$ mineral, $3.90 \%$ ash, $0.33 \%$ calcium. The demand of finger millet is in increasing trend due to its nutritional value besides it is also used as a staple food grains in some parts of India. Straw makes valuable fodder for both drought and milking animals. Grain may also be malted and a flour of the malted grain can be used as cakes or porridge and a nourishing food for infants and physically weak people. Finger millet is considered whole food for diabetes. Crop geometry depends on various factors such as plant type, season, soil fertility levels and age of seedlings. The ideal crop geometry has to be adopted for getting optimum plant stand in the field which results in higher yield. In finger millet the optimum plant density of plant population per unit area under appropriate spacing to obtain maximum yield. The productivity of finger millet can be increased by applying judicious combination of organic and inorganic fertilizers which helps to improve the soil health as well as the productivity of finger millet (Ramamurthy et al., 1993). Finger millet is normally grown on poor, marginal soils with imbalanced nutrient applications. Among various nutrients nitrogen is an inevitable nutrient for any crop. Nitrogen $(\mathrm{N})$ as an element has been identified to be of critical importance to high yield of finger millet during vegetative development, flowering and seed set (Korir et al., 2018) ${ }^{[4]}$. Combined application of nitrogen through organic manures and fertilizers generally produces higher crop yield than sole 
application. Vermicompost has been recognized as a low cost and environmentally sound process for treatment of many organic wastes. Vermicompost prepare from animal waste sources, usually contained more mineral elements than commercial plant growth media (Edwards and Burrows, 2010) ${ }^{[3]}$. In the vermicompost production, the complex organic residues are biodegraded by symbiotic association between earthworms and microbes.

\section{Material and Methods}

A field experiment was carried out to study the "Influence of Different Spacing and Nutrient Sources on Yield and Economic of Zaid Finger Millet (Eleusine coracana L. Gaertn) under Eastern UP condition" during Zaid season 2020 at Crop Research Farm (CRF) SHUATS, Department of Agronomy, Naini Agricultural Institute, Sam Higginbottom University of Agriculture, Technology and Sciences, Prayagraj, Uttar Pradesh. The Crop Research Farm is situated at $25.75^{\circ} \mathrm{N}$ latitude, $87.19^{\circ} \mathrm{E}$ longitude and at an altitude of $98 \mathrm{~m}$ above mean sea level. The soil of the experimental plot was sandy loam in texture, nearly neutral in soil reaction $(\mathrm{pH}$ 7.4), low in organic carbon $(0.48 \%)$, medium in available $\mathrm{N}$ $(278.93 \mathrm{Kg} / \mathrm{ha})$, available $\mathrm{P}(19.03 \mathrm{Kg} / \mathrm{ha})$ and available $\mathrm{K}$ $(238.1 \mathrm{Kg} / \mathrm{ha})$. The field trial was laid out in a randomized block design with consisted of nine treatments replicated thrice viz., $\mathrm{T}_{1}: 20 \mathrm{~cm} \times 10 \mathrm{~cm}+100 \%$ RDN, $\mathrm{T}_{2}: 20 \mathrm{~cm} \mathrm{x} 10$ $\mathrm{cm}+100 \% \mathrm{~N}$ through vermicompost, $\mathrm{T}_{3}: 20 \mathrm{~cm} \times 10 \mathrm{~cm}+$ $50 \% \mathrm{RDN}+50 \% \mathrm{~N}$ through vermicompost, $\mathrm{T}_{4}: 30 \mathrm{~cm} \mathrm{x} 10$ $\mathrm{cm}+100 \%$ RDN, $\mathrm{T}_{5}: 30 \mathrm{~cm} \times 10 \mathrm{~cm}+100 \% \mathrm{~N}$ through vermicompost, $\mathrm{T}_{6}: 30 \mathrm{~cm} \times 10 \mathrm{~cm}+50 \% \mathrm{RDN}+50 \% \mathrm{~N}$ through vermicompost, $\mathrm{T}_{7}: 40 \mathrm{~cm} \times 10 \mathrm{~cm}+100 \%$ RDN, $\mathrm{T}_{8}$ : $40 \mathrm{~cm} \times 10 \mathrm{~cm}+100 \% \mathrm{~N}$ through vermicompost and $\mathrm{T}_{9}: 40$ $\mathrm{cm} \times 10 \mathrm{~cm}+50 \% \mathrm{RDN}+50 \% \mathrm{~N}$ through vermicompost. Finger millet variety "Godra-OT" (Farmer variety in Orissa) was used during Zaid season 2020. Vermicompost was applied on $\mathrm{N}$-equivalent basis. All nutrients were applied through soil as urea, single super phosphate (SSP) and muriate of potash (MOP). Full dose of $\mathrm{P}, \mathrm{K}$ and vermicompost was applied basal for respective plots, half dose of $\mathrm{N}$ (as urea) was applied basal and the remaining at active tillering stage. The growth parameters were recorded at periodical intervals of $20,40,60,80 \mathrm{DAS}$ and at harvest stage from the randomly selected five plants in each treatment. Statistically analysis was done and mean compared at $5 \%$ probability level for significant results.

\section{Result and Discussion \\ Grain Yield (t/ha), Biological Yield (t/ha) and Harvest Index $(\%)$}

Data pertaining to grain yield ( $\mathrm{t} / \mathrm{ha})$, biological yield ( $\mathrm{t} / \mathrm{ha})$ and harvest index $(\mathrm{HI} \%)$ is presented in Table 1. The treatment with spacing of $20 \mathrm{~cm} \times 10 \mathrm{~cm}+50 \%$ RDN $+50 \%$ $\mathrm{N}$ through vermicompost were recorded maximum grain yield (2.74 t/ha) and biological yield (7.41 t/ha) which was significantly superior over all the treatments. However, in case of grain yield and biological yield treatment with spacing of $20 \mathrm{~cm} \times 10 \mathrm{~cm}+100 \%$ RDN and spacing of $30 \mathrm{~cm} \times 10$ $\mathrm{cm}+50 \% \mathrm{RDN}+50 \% \mathrm{~N}$ through vermicompost were statistically on par with treatment of spacing $20 \mathrm{~cm} \times 10 \mathrm{~cm}+$ $50 \%$ RDN $+50 \% \mathrm{~N}$ through vermicompost. Harvest index (\%) shows non - significant result among different treatments but it found maximum (37.03\%) under more biomass producing treatment $20 \mathrm{~cm} \times 10 \mathrm{~cm}+50 \% \mathrm{RDN}+50 \% \mathrm{~N}$ through vermicompost. Lower grain yield was recorded under wider spacing because total number of plants per unit area was far lesser than with closer planting. Optimum planting pattern is the prerequisite for proper utilization of growth resources and ultimately to exploit the potential productivity of any crop. This is in agreement with the findings of Rafey and Srivastava, (1998) ${ }^{[7]}$. A wider spacing $30 \mathrm{~cm} \mathrm{x} 10 \mathrm{~cm}$ and $40 \mathrm{~cm} \times 10 \mathrm{~cm}$ is significantly lesser dry weight compared to the closer spacing $20 \mathrm{~cm}$ x $10 \mathrm{~cm}$. Therefore, more plant material due to higher plant population. The closer spacing may have been lead to the higher plant population that resulted in higher number of heads and more grains compared to wider spacing. The closer spacing may not affect yield due to the adverse effect of competition between plants associated with closer spacing, this also agreed by Shinggu et al., (2009) ${ }^{[9]}$ and Korir et al., (2018) ${ }^{[4]}$. The judicious use of inorganic and organic source has beneficial effect on physiological process of plant metabolism and growth there by leading to higher grain yield. The nitrogen is easily available due to mineralization of organics. Therefore, the shoot and root growth influenced so it absorption of other nutrient favored. Similar results were obtained by Varalakshmi et al., (2005) [11], Yakadri and Reddy, (2009) [12], Umesh et al., (2006) ${ }^{[10],}$ Basavaraju and Purushotham, (2009) ${ }^{[2]}$.

\section{Economics}

Economics of crop production is dependent on market price of inputs and quantity of output produced and price in the market (Aparna et al., 2020). Cost of cultivation varied due to variation in spacing and nutrient sources from ₹30528.35/ha to $₹ 31106.95 / \mathrm{ha}$. As result found grain and biological yield varies from treatment to treatment. The maximum gross return and net return was observed in high yield producing treatment, i.e. $20 \mathrm{~cm} \times 10 \mathrm{~cm}+50 \% \mathrm{RDN}+50 \% \mathrm{~N}$ through vermicompost. The maximum gross return (₹90104.00/ha), net return (₹59095.25/ha) and B:C ratio (1.90) were found under treatment of spacing $20 \mathrm{~cm} \times 10 \mathrm{~cm}+50 \% \mathrm{RDN}+$ $50 \% \mathrm{~N}$ through vermicompost which was given ₹18813.5/ha more net return on lowest yield producing treatment (Table 2).

The various return obtained from different treatments was due to prevailing prices and relative advantage by crop. The high grass return and net return under treatment $20 \mathrm{~cm} \mathrm{x} 10 \mathrm{~cm}+$ $50 \% \mathrm{RDN}+50 \% \mathrm{~N}$ through vermicompost it all because crop was well established and nutrient availability in conveniently way choice increase yield. Similar results reported by Pallavi et al., (2016) ${ }^{[6]}$.

The closer spacing and applying judicious combination of organic and inorganic sources of nitrogen progressively increased the net returns and $\mathrm{B}: \mathrm{C}$ ratio of finger millet crop. 
Table 1: Grain Yield, Biological Yield and Harvest Index of Finger Millet as influenced by Different Spacing and Nutrient Sources

\begin{tabular}{|c|c|c|c|}
\hline Treatments & Grain Yield (t/ha) & Biological Yield (t/ha) & Harvest Index (\%) \\
\hline $20 \mathrm{~cm} \times 10 \mathrm{~cm}+100 \%$ RDN & 2.69 & 7.31 & 36.86 \\
\hline $20 \mathrm{~cm} \times 10 \mathrm{~cm}+100 \% \mathrm{~N}$ through vermicompost & 2.37 & 6.66 & 35.58 \\
\hline $20 \mathrm{~cm} \times 10 \mathrm{~cm}+50 \% \mathrm{RDN}+50 \% \mathrm{~N}$ through vermicompost & 2.74 & 7.41 & 37.03 \\
\hline $30 \mathrm{~cm} \times 10 \mathrm{~cm}+100 \% \mathrm{RDN}$ & 2.35 & 6.62 & 35.49 \\
\hline $30 \mathrm{~cm} \times 10 \mathrm{~cm}+100 \% \mathrm{~N}$ through vermicompost & 2.42 & 6.66 & 36.37 \\
\hline $30 \mathrm{~cm} \times 10 \mathrm{~cm}+50 \% \mathrm{RDN}+50 \% \mathrm{~N}$ through vermicompost & 2.62 & 7.17 & 36.60 \\
\hline $40 \mathrm{~cm} \times 10 \mathrm{~cm}+100 \% \mathrm{RDN}$ & 2.28 & 6.49 & 35.20 \\
\hline $40 \mathrm{~cm} \mathrm{x} 10 \mathrm{~cm}+100 \% \mathrm{~N}$ through vermicompost & 2.09 & 6.22 & 33.61 \\
\hline $40 \mathrm{~cm} \times 10 \mathrm{~cm}+50 \% \mathrm{RDN}+50 \% \mathrm{~N}$ through vermicompost & 2.15 & 6.22 & 34.52 \\
\hline $\operatorname{SEm}( \pm)$ & 0.0462 & 0.2391 & 0.8797 \\
\hline $\mathrm{CD}(\mathrm{p}=0.05)$ & 0.1385 & 0.7170 & NS \\
\hline
\end{tabular}

Table 2: Total Cost of Cultivation, Gross Return, Net Return and B:C ratio of Finger Millet as influenced by Different Spacing and Nutrient Sources

\begin{tabular}{|c|c|c|c|c|}
\hline Treatments & \begin{tabular}{|c|}
$\begin{array}{c}\text { Total Cost of Cultivation } \\
(₹ / h a)\end{array}$ \\
\end{tabular} & $\begin{array}{c}\text { Gross Return } \\
(\mathbf{₹} / \mathbf{h a})\end{array}$ & $\begin{array}{l}\text { Net Return } \\
(\mathbf{F} / \mathbf{h a})\end{array}$ & B:C ratio \\
\hline $20 \mathrm{~cm} \times 10 \mathrm{~cm}+100 \% \mathrm{RDN}$ & \begin{tabular}{|l|}
30928.35 \\
\end{tabular} & 88584 & 57655.65 & 1.86 \\
\hline $20 \mathrm{~cm} \times 10 \mathrm{~cm}+100 \% \mathrm{~N}$ through vermicompost & 31106.95 & 78814 & 47707.05 & 1.53 \\
\hline $20 \mathrm{~cm} \times 10 \mathrm{~cm}+50 \% \mathrm{RDN}+50 \% \mathrm{~N}$ through vermicompost & 31008.75 & 90104 & 59095.25 & 1.90 \\
\hline $30 \mathrm{~cm} \times 10 \mathrm{~cm}+100 \% \mathrm{RDN}$ & 30688.35 & 82517 & 51828.65 & 1.68 \\
\hline $30 \mathrm{~cm} \times 10 \mathrm{~cm}+100 \% \mathrm{~N}$ through vermicompost & 30866.95 & 80083.3 & 49216.35 & 1.59 \\
\hline $30 \mathrm{~cm} \times 10 \mathrm{~cm}+50 \% \mathrm{RDN}+50 \% \mathrm{~N}$ through vermicompost & 30768.75 & 86534 & 55765.25 & 1.81 \\
\hline $40 \mathrm{~cm} \times 10 \mathrm{~cm}+100 \%$ RDN & 30528.35 & 76344 & 45815.65 & 1.50 \\
\hline $40 \mathrm{~cm} \mathrm{x} 10 \mathrm{~cm}+100 \% \mathrm{~N}$ through vermicompost & 30706.95 & 70988.7 & 40281.75 & 1.31 \\
\hline $40 \mathrm{~cm} \times 10 \mathrm{~cm}+50 \% \mathrm{RDN}+50 \% \mathrm{~N}$ through vermicompost & 30608.75 & 72274 & 41665.25 & 1.36 \\
\hline
\end{tabular}

\section{Conclusion}

It is concluded that due to the higher plant population at the closer spacing of $20 \mathrm{~cm} \mathrm{x} 10 \mathrm{~cm}$ the number of heads per plant was higher compared to wider spacing. This led to a significantly higher grain yield for the closer spacing as compared to wider spacing. The integrated use of 50\% RDN $+50 \% \mathrm{~N}$ through vermicompost is the best nutrient management practice that can be adopted to obtain better yield with high benefit cost ratio. Therefore, it is recommended to farmers for receiving higher yield and economic benefits of finger millet.

\section{Acknowledgement}

I express gratitude to my advisor Dr. Rajesh Singh for constant support and guidance. I am indebted to Prof. (Dr.) Joy Dawson, Dr. Vikram Singh, Dr. Umesha. C and Dr. Shikha Singh, Department of Agronomy.

\section{Reference}

1. Aparna K, Bhanu KR, Vani KP, Ramprakash T. Growth and yield of finger millet as influenced by crop residue composting. Journal of Pharmacognosy and Phytochemistry 2019;8(4):1108-1111.

2. Basavaraju TB, Purushotham S. Integrated nutrient management in rainfed ragi (Eleusine coracana L. Gaertn). Mysore J Agri. Sci 2009;43:366-368.

3. Edwards CA, Burrows I. The potential of earthworm composts as plant growth media. In: Earthworms in environmental and waste management, Edwards, C.A. and S.P.B. Newhauser (Eds.) Academic Publication 2010.

4. Korir A, Kamau P, Mushimiyimana D. Effect of Fertilization and Spacing on Growth and Grain Yields of finger Millet (Eleusine coracana L.) In Ainamoi, Kericho County, Kenya. International Journal of Advanced Research and publication 2018, 2456-9992.

5. Mckeown NM. Whole grain intake is favorably associated with metabolic risk factors for type 2 diabetes and cardiovascular disease in the Framingham offspring study. American Journal of Clinical Nutrition Research 2002;76:390-398.

6. Pallavi Ch, Joseph B, Aariff Khan MA, Hemalatha S. Economic Evaluation of Finger Millet under different Nutrient Management Practices. Int. J Curr. Microbiol. App. Sci 2016;5(8):690-698.

7. Rafey A, Srivastava VC. Effect of cultivation, seedlings rate and spacing on grain yield of rainfed Finger Millet. Indian Journal of Agronomy 1998;33(3):331-332.

8. Ramamurthy K, Christoper Louduraj A, Alagudurai S, Kandaswamy OS. Effect of crop residue management of early season legumes on the succeeding rainfed finger millet. Madras Agril. J 2004;91(4-6):180-183.

9. Shinggu CP, Dadari SA, Shebayan JAY, Adekpe DI, Mahadi MA, Mukhtar A et al. Influence of spacing and seed rate on weed suppression in Finger Millet (Eleusine coracana. Gaertn). Middle East Journal of Scientific research 2009;4(4):267-270.

10. Umesh MR, Sharanappa Shrinivasa KR, Kumar KKC. Effect of cropping systems and integrated nutrient management on growth, yield and nutrient uptake of finger millet under rainfed conditions. Crop Res 2006;31:366-369.

11. Varalakshmi LR, Srinivasamurthy CA, Bhaskar S. Effect of integrated use of organic manures and inorganic fertilizers on organic carbon, available $\mathrm{N}, \mathrm{P}$ and $\mathrm{K}$ in sustaining productivity of groundnut-finger millet cropping system. J Indian Soc. Soil Sci 2005;53:315-318.

12. Yakadri M, Reddy APK. Productivity of pearl millet (Pennisetum glaucum L.) as influenced by planting pattern and nitrogen levels during summer. J Res. ANGRAU 2009;37:34-37. 